\title{
THE DIVERGENT DEVELOPMENT OF TWO VILLAGES IN THE AUSTRO-HUNGARIAN BORDER REGION*
}

\author{
By \\ Monika Maria Varadi and Doris Wastl-Walter**
}

\begin{abstract}
This article is the carefully-documented experience of two villages, once closely united, physically, historically, economically, and of their divergent development after their traumatic separation by the iron curtain. The villages of Moschendorf and Pinkamindszent lie within sight of each other in what was once the heart of the Austro-Hungarian Empire. The division of the region by an international border has caused irreversible changes, strongly related to the ideological and governmental under which each has lived.
\end{abstract}

\section{RESUMEN}

Este artículo muestra la experiencia, cuidadosamente documentada, de dos pueblos alguna vez unidos, física, histórica y socialmente, y de su desarrollo divergente después de su separación traumática a causa de la cortina de hierro. Los pueblos de Moschendorf y Pinkamindszent están ubicados a la vista uno del otro, dentro de lo que anteriormente era el corazón del imperio Austro-Húngaro. La división de la región por la frontera internacional ha provocado cambios irreversibles, estrechamente relacionados con los sistemas ideológicos y de gobierno debajo de los cuales cada uno ha vivido.

\section{THE AIM OF THE INVESTIGATION}

\section{The Research Subject and the Methods}

The fall of the iron curtain opened the way for comparative research work concerning the differences in regional development in the East and in the West, in this concrete case along the Austro-Hungarian border. Eastern Austria (Burgenland) had been part of the Hungarian half of the AustroHungarian Empire, and had, to a large extent, the same socio-economic

\footnotetext{
* This article was accepted in May of 1996 to be publicated in Estudios Fronterizos.

**Monika Maria Varadi is research scholar at the Department for Regional Research of the Hungarian Academy of Sciences in Budapest. She has studied sociology and her main interest is sociology of rural areas. Doris Wastl-Walter has studied geography in Vienna, Austria and is now Associate Professor in the Department of Geography at the University of Klagenfurt, where she is also vice-rector.
} 


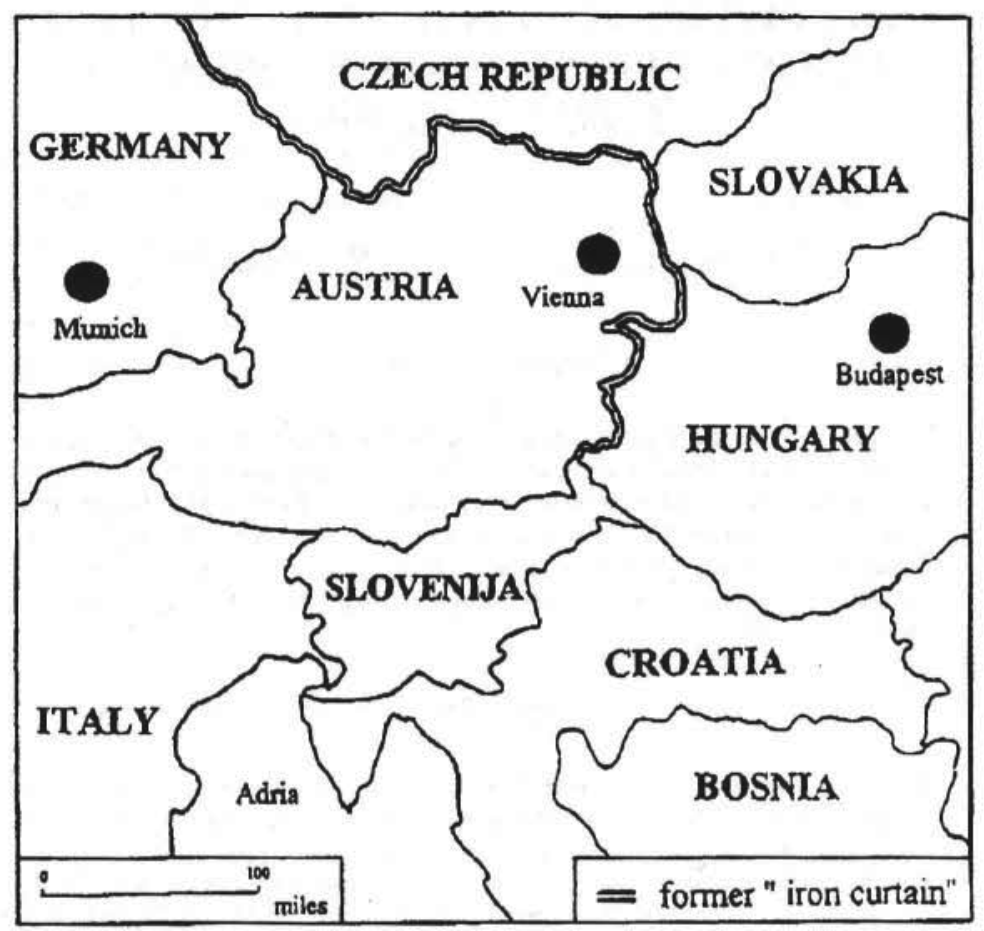

Figure 1. Central Europe, 1995.

structure as the Hungarian neighbourhood. In 1921, the area was divided by an international border; therefore East Austria and Western Hungary have had a divergent development. Life in this border region is determined by two restrictions: a) the location in a peripheral area in each of the two national settlement systems; b) the location at the iron curtain, a geopolitical rupture, which determines to a different extent the regional development on both its sides (see figure 1).

This case study, a comparison of two border villages, formerly in many ways connected, but which had to relinquish any contact since 1948, reveals the consequences proceding from this location. The effects of these two geographical restrictions can be shown not only in the social and economic development of the two local societies, but also in the individual possibilities for self-realization. The iron curtain has not only been a border; it is a multiple rupture: State border, language border, ideological 
border, border between different social systems, and a military blockade between differently-developed countries.

For our concrete work we have chosen the two villages Pinkamindszent (Allerheiligen) and Moschendorf (Nagysároslak), situated directly on the border at a distance of 2 kilometers from each other. The two villages were connected until 1948 by contacts of different types and intensities; they had in 1900 nearly the same number of inhabitants, and a similar demographic and socio-economic structure. There is also visual contact between these two villages: you can see from one village to the other over the iron curtain.

Present plans call for a check point to be installed there, but it probably will not be open to international traffic but only to the Austro-Hungarian local traffic. Both sides relate to this with differing expectations.

The data base of our work is, on the one band, the statistical information of the census data; on the other hand, we used explorative methods for a detailed investigation. The research period is in general the twentieth century. Sometimes we got information from the last century, and we tried to verify this information by interviewing parents and grandparents. For the present-day situation, we did standardized interviews in May, 1990. In Moschendorf, it was possible to interview 69 households; in Pinkamindszent there were 32 , to complete our study. We had several explorative interviews with elderly people. We also made maps of the functional and architectural structure of the villages, took photos, and checked the files.

The events of our century have greatly affected the people of these two villages. The reports include very personal statements. But this oral history also gives us an idea of the collective memory (see Halbwachs) which still influences today the daily life and the social relationships.

We structured this contribution to follow epochs marked by important events. The most important of them was the establishment of a border in the formerly united country. This border only became important in determining possibilities in the lives of individuals, families and communities, when it also became the border between two political systems.

The Two Villages Moschendorf (Nagysároslak) and Pinkamindszent (Allerheiligen)

Up to 1921, Pinkamindszent was not only the community center of the surrounding Hungarian villages, but also of the villages of the Germanspeaking minority, like Moschendorf. 


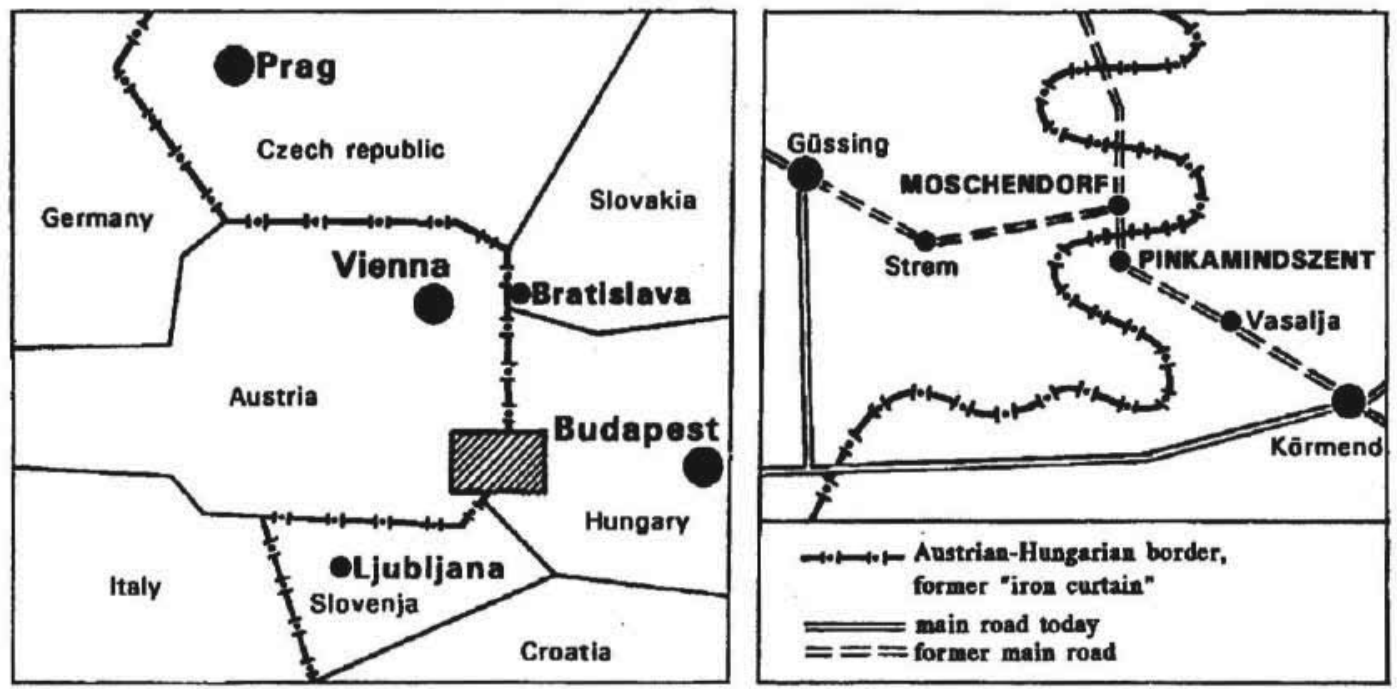

Figure 2. The Location of the Two Investigated Villages Moschendrf and Pinkamindszent. 
Pinkamindszent, with 194 inhabitants today, is situated in the Komitat Vas, about $10 \mathrm{~km}$ from Kormend; from 1969 to 1990 it was part of the community of Vasalja (358 inhabitants). Today it is politically independant, but without financial resources or economic power. Moschendorf (468 inhabitants), has been part of the community of Strem (605 inhabitants) since 1973. Untill 1973, Moschendorf was an independant community, but there are no present plans to try for independance again.

Concerning the traffic situation, Pinkamindszent had an advantage, compared to Moschendorf, because it lies on the road from Körmend to Güssing. It had a railway-station, while Moschendorf was out of the way, and had no railway connections. Since the fifties, both villages have had this remote location. Today you have to make a $50 \mathrm{~km}$ detour to get from one place to the other.

Both villages have a similar natural potential for agriculture. The agrarian structure was also similar: a farmstead included pastures, grainfields, forest (in general in collective ownership), and in Moschendorf, vineyards. The main industry was cattle breeding and dairying. Both villages also had the same problems: as the agriculture could not support the population under the given ownership and utilization conditions (just as in many other parts of central Europe), a large percent of the population emmigrated. In 1900, both village also had similarities in the number of inhabitants and the demographic structure. They were homogenous as concerning the religion, both were Roman Catholic with their own parish. As to language: the people of Pinkamindszent spoke Hungarian; those of in Moschendorf, German.

In Pinkamindszent the number of inhabitants showed a continous decline untill 1949 because of emigration, but from this moment on, the decrease in population was very dramatic as a consequence of the radical political and economic changes. Considering the decreasing number of young people and the increasing proportion of old people (at present, about half of the population) this process seems irreversible. During this century, the number of inhabitants went down to a quarter of the population at the turn of the century, and a change in the trend cannot be foreseen. Also, in Moschendorf a continous decline in population can be seen, but the trend has not increased since the fifties, and over the last few years it almost stopped. Thus, the demographic structure is different too: the percentage of young people (less than twenty years old) is $23.5 \%$, that of elderly people (over 60 years old) is $31 \%$. This means that the total population only decreased to half the number of the population at the turn of the century, and the trend was interrupted some years ago. 
Table 1. Population Development and Age Structure of the Two Investigated Communities (1900-1991).

\begin{tabular}{|c|c|c|c|c|c|c|c|c|}
\hline \multicolumn{9}{|c|}{ Pinkamindszent (Allerheiligen) } \\
\hline 0 & 1 & 2 & 3 & (\%) & 4 & (\%) & 5 & (\%) \\
\hline 1900 & 132 & 829 & 385 & 46.4 & 376 & 45.5 & 68 & 8.2 \\
\hline 1910 & 135 & 783 & 348 & 44.4 & 363 & 46.4 & 72 & 9.2 \\
\hline 1920 & 134 & 706 & 253 & 35.8 & 360 & 51.0 & 93 & 13.2 \\
\hline 1930 & 138 & 699 & 260 & 37.2 & 363 & 51.9 & 76 & 10.9 \\
\hline 1941 & 164 & 640 & 222 & 34.7 & 330 & 51.6 & 88 & 13.7 \\
\hline 1949 & 151 & 659 & 162 & 24.6 & 394 & 59.8 & 103 & 15.6 \\
\hline 1960 & 149 & 489 & 159 & 30.6 & 231 & 47.3 & 108 & 22.1 \\
\hline 1970 & 136 & 403 & 113 & 28.0 & 181 & 45.0 & 109 & 27.0 \\
\hline 1980 & 123 & 261 & 39 & 14.9 & 126 & 48.4 & 96 & 36.7 \\
\hline 1990 & 107 & 197 & 30 & 15.2 & 85 & 43.1 & 82 & 41.7 \\
\hline \multicolumn{9}{|c|}{ Moschendorf (Nagysaroslak) } \\
\hline 0 & 1 & 2 & 3 & $(\%)$ & 4 & (\%) & 5 & (\%) \\
\hline 1900 & 175 & 928 & 426 & 45 & 436 & & 66 & 7. \\
\hline 1910 & 180 & 834 & 405 & 42.5 & 345 & 47.4 & 84 & 10.1 \\
\hline 1920 & 189 & 894 & 402 & 45.0 & 382 & 42.7 & 110 & 12.3 \\
\hline 1923 & & 814 & & & & & & \\
\hline 1934 & & 745 & & & & & & \\
\hline 1951 & & 623 & 156 & 25.0 & 375 & 60.2 & 92 & 14.8 \\
\hline 1961 & & 586 & 147 & 25.1 & 366 & 62.5 & 73 & 12.4 \\
\hline 1971 & & 561 & 137 & 24.4 & 340 & 60.6 & 84 & 15.0 \\
\hline 1981 & 158 & 469 & 110 & 23.5 & 241 & 51.4 & 118 & 25.1 \\
\hline 1991 & 165 & 468 & 101 & 21.6 & 222 & 47.4 & 145 & 31.0 \\
\hline
\end{tabular}

SOURCE: census data

$0=$ Year.

$1=$ Number of houses 1900-1941/appartments 1949-1991.

2 = Number of inhabitants (1900-1941 present population, 1949-1991 resident population).

$3=$ Number and share of population of 0 to 19 years old.

$4=$ Number and share of population of 20 to $60 / 64$ years old.

$5=$ Number and share of population more than $60 / 64$ years old. 
The same is true of the houses: the number of houses in Pinkamindszent diminished from 132 to 107; in Moschendorf the lowest number was 158 in 1981. Since that time, the number has increased, especially in regard to second homes and houses belonging to retired persons. The difference in the living conditions in the two villages, which can be shown by statistical data and intensive interviews, is the result of a short, but serious and far-reaching process. This we will now discuss in detail.

\section{AUSTRIA-HUNGARY: GRADUAL SEPARATION OVER PERIOD OF YEARS (1900-1948)}

\section{Between Körmend and Güssing}

The two villages investigated are situated in an agricultural area, where at the turn of the century two bigger towns could be found: Körmend and Güssing. Today they have 12,165 and 3,886 inhabitants respectively, but in 1900 Kömend already had three times as many inhabitants as Güssing. In both towns there is an royal castle (belonging to the family Batthyany), but Körmend was always more important as a domain, while Güssing had a very peripherical location at the western Hungarian border.

In Körmend there were several central functions and a better infrastructure and therefore a more differentiated social structure. In the town of Körmend around $1900,28.5 \%$ of the population made a living from agriculture, $47.5 \%$ from trade and business, and $10.2 \%$ from official and personnel services. In Güssing, $43.4 \%$ made a living from agriculture, only $30 \%$ from trade, and $14.9 \%$ from official and personnel services. The farms, shops and trading centers were in general family businesses, which means that people who wanted to get a job or to learn a trade had to go to Szombathely, Budapest, or even to the United states. The two towns could not work as a growth and development factor for the region.

\section{The Rural Society: Small Farmsteads and Tiny Fields Characterized the Agrarian Structure}

The western Hungarian villages in 1900 were, in general, farming villages, with about $80 \%$ of the population working in agriculture. The few artisans were often not indigenous because of the high mobility of this class under the monarchy. The number of artisans did not grow untill the end of the Second World War, because the needs of the local rural population were already met in the region, especially in Kömend. In addition, the requirements of the local people were quite small, because they themselves 
produced most of what they needed (clothing, furniture, etc.). For this reason the local businesses were small, and could not provide for the needs of a whole family. The artisans also had to run a farm, and often it was the duty of the wife to do this. However, not only in the economy were the artisans closely connected with the farmers: their economic strategies corresponded to the norms and values of the agrarian society. They tried to marry into farm families; they invested their profit, not in the modernization of their businesses, but in buying farm land.

As a consequence of the egalitarian heritage system (Segalen, 1984), in which the inheritance as a whole, and every part thereof it is divided equaly among the heirs, and because birth control was unknown or unacceptable as a legal strategy, the farmsteads were very small. The average size in Moschendorf was 6.3 joch $^{*}$ (except for the large estates of the family Battyany), and in Pinkamindszent, 7,4 joch (corrected). Agriculture served mainly for self-support, demonstrable in the mixed farming. Farms produced hardly anything for market; if they did, it was usually only milk.

To avoid further splitting of the property, and to enlarge it if possible, in both local societies several strategies were applied: the most important of them was marriage. In our investigation, we found in both villages a very strong endogamy. There were also, because of the different languages, two separate circles. Among more than $80 \%$ of our interviewees, both grandparents came from the same village. Among the young people as well, this trend is unbroken: in more than $60 \%$ of the cases, the marriage partner is from the same village. In nearly every family there were children who were not marriageable because of the endogamy, or who were not allowed to marry, in order to avoid splitting the property any more. As families had no birth control, the average number of children was very high, even if only half of the children born could survive to adulthood. Women also had to bear children as long as they were capable of childbearing, because as long as small children lived in the house, the inheritance was not to be divided among the heirs.

In each village, among the 10 to 15 families by those who had a larger farmstead (15 to 20 joch with 20 to 25 cattle), there was also used another strategy, which cannot be shown by the official statistics: in spite of the legal division of the inherited, property the heirs ran the farm together. This kind of farm management was brought about by small advances in modemization (especially machines and equipment) together with the splitting system, but it also prevented further development, because all adults were involved in this kind of organization.

\footnotetext{
* Area unit.
} 
In general there were small farms only. In Moschendorf the situation was even worse than in the neighbouring village, because out of 271 rural workers, only 101 owned their own; 74 of these properties were under 10 joch. In Pinkamindszent it was nearly the same; among 310 rural workers, 154 owned their own fields; 105 of these owned a very small farmstead.

In spite of all strategies, in these families especially, agriculture could not supply the needs of the continuously growing population. Since the seventies of the last century emigration already seemed the only suitable solution for young people of this western Hungarian region. Between 1890 and 1914, about 33,000 persons left this region, usually to go to the industrial regions of North America: to Chicago, Pennsylvania and New York. From 1918 to 1938, about 25,000 persons from Burgenland (the new name for the then Austrian part of western Hungary) went overseas, to many countries, including Canada, Argentina, Brazil and Bolivia. The peak emigration year was 1923, with 6,683 emigrants (see Dujmovits, 1975). During the Hungarian era of the monarchy, the number of emigrants to America is estimated for the time from 1867 to 1918 , at about 2 million, among them 1.5 million to the United States. $75 \%$ of these emigrants were farmers, half of them day laborers. Only 33\% were Hungarians, which means there was a high percentage from the minorities, especially from the non industrialized periphery (see Romsics, 1985).

Moschendorf and the neighbouring Deutsch Schutzen were the communities with the highest number of emigrants at that time. In nearly every family one or more members emigrated, mostly to the Unites States, sometimes also to Canada or Argentina.

For the rural society, this safety valve of emigration signified that pressure in favor of fundamental agrarian reform was not too great. Therefore, no real change can be shown, the system of the ownership of possessions, and of farm management were handed down. As a result, emigration as a personal solution continued untill the sixties. There are families where members of three generations emigrated. Many of them went to America, with the idea of coming back when they had saved enough money. Although many of them had married there a partner from their home village, only 11 families came back. The family members in the States played an important role in the lives of those who remained at home. They helped by sending parcels of needed supplies, and introduced modern products in these villages (for example, slips!). Even a long time

1 A typical example is a family, in which of the 12 children born, 6 died in childhood, and 5 emigrated ( 4 sons to Buenos Aires, New York, Florida and Budapest, respectively, 1 daughter to New York). Only the youngest daughter stayed at home, and inheritad the small farm. 
after the Second World War, American parcels with food (chocolate) and clothing were an important help for those people. "Formerly we did not have anything, we were poor people. My father had an aunt in the USA, and she sent us clothes. I went to my first communion in an American dress, to my confirmation in an American dress, and I also married in an American coat. After the War thousands and thousands of parcels came from our American relatives and helped us". (Woman in Moschendorf).

In Pinkamindszent only 31 persons emigrated, mostly before the First World War. Six men went several times to the States, but finally came back and stayed at home. In general, they went to America for economic reasons; in only two cases we heard that they went because they were afraid of the military service. The aim was to get money to create a secure livelihood in the local society. Most of these who emigrated came from the very small farms and they wanted to earn enough to ensure having farmland enough to provide for their needs. It is typical for Pinkamindszent as a part of the majority and leading nation that in general people migrated to Budapest or other urban centers.

Concerning the socio-economic structure, both villages were characterized by a traditional agrarian society untill the beginning of the sixties. They had in common not only the problem of the splitting of the properties, but also the fact that the social structure did not show a real differentiation. There were no important social differences; life in the local societies was molded by hard work, frugality, moderatation and religious devotion, and the members of the local society were judged by this.

Also the means of communication and the social life in both villages were similar. In the center was the fire brigade building where balls were held especially at camival time. To these balls, the inhabitants of the neighbouring villages were also invited. In addition, for men in Moschendorf, the wine cellars were places for social life on Sundays; in Pinkamindszent men met together in the inns and workshops of the artisans. Children and young people usually met at events organized by

Table 2. The Structure of the Farmers in Moschendorf and Pinkamindszent 1900 and 1950.

\begin{tabular}{lrrrr}
\hline & \multicolumn{2}{c}{ Moschendorf } & \multicolumn{2}{c}{ Pinkamindszent } \\
& 1900 & 1950 & 1900 & 1950 \\
\hline Working in farms & 271 & 370 & 310 & 261 \\
With an own farmstead & 101 & 139 & 154 & 116 \\
Under 10 joch area & 74 & 121 & 105 & 78 \\
\hline
\end{tabular}


the teacher, cantor or pastor. Married women saw each other when going to church, or at the milk collection center.

This picture of a traditional agrarian society generally holds true untill the sixties, although historical events brought about the first ruptures earlier.

\section{The National Border is Established (1921)}

The present-day border between Austria and Hungary was established in 1921. Up to that time the two villages had lived side by side, and together. Now they became border villages, which changed their situation fundamentally, while not really causing it to deteriorate. The devision of the area by an international border did not bring with it either basic social upsets nor shocks on an individual level, because the physical division followed in general the language border. Pinkamindszent lost the German-speaking villages of the community, but it remained the community center. Moschendorf lost the important traffic connections, and had to build up its own structure. Two-thirds of the community border were also international border, which crearly shows the out-of-the-way-location. In Moschendorf the official language was also changed; school lessons were now in German and Hungarian, as officialese disappeared. This was the reason why, as time passed, knowledge and use of the other languages were gradually lost.

\section{Border Crossing Relations and Trade}

After the border was established, Körmend remained the economic and cultural center of the region up to the time of the Second World War; for example, Austrian families continued to send their children for higher education to Hungary (Körmend, Köszeg). In Burgenland such a wellfunctioning system of urban centers could be set up only little by little, and so the micro-region of Körmend was not inmediately destroyed. On the contrary, new economic relations were established, and many families profited from them, especially from smuggling: People from Moschendorf bought sugar or other staples in Pinkamindszent. For other things, like clothes, Körmend was still the shopping place; but now it was reachable only by crossing the international border. But there was also big-business smaggling; for example, cattle were brought into Austria to be sold there. People from Pinkamindszent went across the border to work illegally in Austria. Those who had fields on the other side of the border could go there with a border pass, and also social contacts lasted for a long time. Guests 
from Austria also came to the Mardi Gras balls in Pinkamindszent and when Hungarians wanted to make a religious pilgrimage they were invited to Moschendorf. Thus, a lot of intercultural and neighbourly contacts existed untill the end of the Second World War, when all that ended. The border had been permeable; traditional social and business relations could be maintained, even if they were sometimes illegal. The decisive rupture came only after the end of the war.

\section{THE PARTING OF THE WAYS (1945-1960)}

The last days of the War and the first years after were very difficult for this region. For two weeks the military front line went right through these villages, and after the War, the soldiers and fereign workers who left the region by train from Pinkamindszent did a lot of damage there. As people had no machines, no seeds and no fertilizer, no animals and no workers, the agricultural situation was truly desperate. It took some years to reach crop yields equal to those of the time before the War. Slowly the economic situation improved, also with help from the U.S.: "Yes, my mother sent us parcels. She was also old, she could not do much. But my cousin and others could help us a little - also with money - my cousin, they could".

Another possibility for getting money in Moschendorf was still smuggling. In the fifties, things changed. Especially the Southern Burgenland found itself in an complelely new geopolitical situation. It had always been a quite underdeveloped region, but it was in the center of the Austro-Hungarian Monarchy, where it had a long history of strong interconnected of relationships, and it had lost its historical ties only little by little during the period between the two Wars. Now people found themselves on the outermost edge of Western Europe, in the Russian zone of occupation, in the Eastern periphery of Austria and without any possibility of contacting their former near neighbours. As a result, the development of the agricultural structure and industrialization took much more time than in other parts of Austria, and emigration, mostly to the United States, was still important.

In 1950 both villages had about 630 inhabitants (Pinkamindszent, 1949:659; Moschendorf, 1951:623). In the nineties both lost population, but Monschendorf lost only $25 \%$, while Pinkamindszent lost $70 \%$.

For Pinkamindszent the shock was even worse than for Moschendorf. Its status changed from that of a region in the heart of Central Europe to that of a region on the extreme periphery of the East, just in front of the Iron Curtain, which had been established there in 1948. People no longer had the freedom to contact their neighbouring village, which they could 


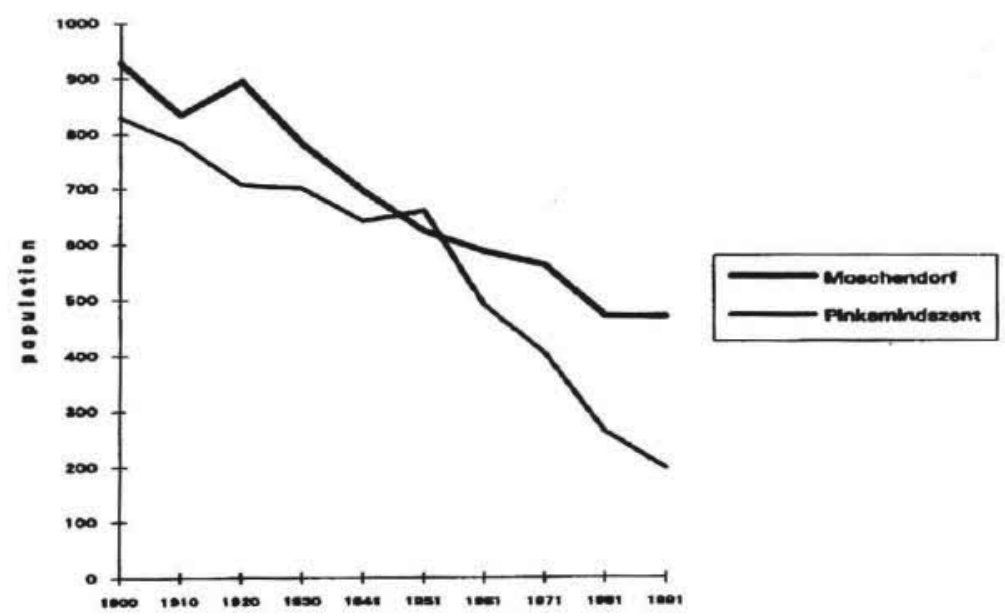

Figure 3. The Decline of Population in the Two Investigated Villages. Source: Census Data.

see from their homes. As a result, in 1948/1949 saw the beginning of an emigration which has changed irreversibly the demographic structure of the local society. The process went on continously; but twice the dimension increased quickly and even dramatically: between 1949 and 1960, and after 1970. The whole process, and in particular events during these two periods can be seen as a (logical) consequence of the political practice of state socialism. To a larger extent as well, this demographical erosion can be interpreted as one factor in a system which modernizes basically the living conditions of a society. In the life of the population of Pinkamindszent, the consequences of the compulsory socialist modernization are linked with the effects of the location at the border.

The people felt the consequences of the "Sowjet-Modell" for the first time when the border was completely closed. Instead of the permeable and penetrable border of the time from 1921 to 1948, the Iron Curtain was not only a physical, but also a socologically and psychologically menacing reality. Furthermore, they had not only lost their fields in the area of Moschendorf, but also many fields in Pinkamindszent were taken out of production. The community had a $50 \mathrm{~m}$ wide and $19 \mathrm{~km}$ long border area where they were allowed to go, and to cultivate there, by special permit only. The border villages like Pinkamindszent were not only closed on the western side to Austria, but also closed to the rest of Hungary: the border zone was an isolated area where people were allowed to go by special 
permission only, and where those who lived there had to prove this with documents. From the point of view of the people concerned, it meant that we became a forgotten community.

Another consequence of the isolation was that there were no newcomers, so that these areas did not receive other social groups as did the small villages they had given up in other parts of Hungary (see Kovács, 1987 and 1990).

Notwithstanding the fact that Pinkamindszent was in a forgotten area, the people still had to suffer all the political changes that affected the country as a whole ("Kulak" lists, taxes, collectivization of the bigger busineses). As a consequence of these political measures, these began to be a dissolution of the local society, imperceptible for the moment. "For the moment", because the legal position concerning property was not changed, for the time being and the strong tradition of the rural way of life led to the fact that untill 1959 no farmstead had been given up. But by 1945 and particularly after 1949-1950, the rural workers, small farmers and artisans had already started to send their children to the socialist industries and to the big towns (mostly Budapest and Szombathely), where they became wageworkers. It is typical, and a consequence of the special position of the artisans in the local society, that in the new distribution and organization of power, artisans, or children from artisan families had the new positions. This group of nearly unpropertied artisans in particular expected much from the new system. The farmers - following their old strategies- reacted differently to these changes in their social surroundings. The farm families, even under aggravating conditions, continued with business as usual, at the given techmical level, and in the traditional working organization of the family.

But the younger generation slowly changed their attitude towards agriculture. For them, life as a farmer was no longer the self-evident choice, and surely not the only prospect for life. Also, some parents no longer saw a chance for the future in the home village, and sent their sons to higher schools. (The future for the girls was always seen as a good marriage!).

The events of 1956 were experienced in Pinkamindszent in a very disciplined and relieved manner. People were very glad to be able to contact old friends. Their greatest surprise was the poverty on the other side of the border: at that time the Southern Burgenland was still poor, and for a Western European country, relatively underdeveloped. As to the demographic situation of the local society, it is important to note that between 20 and 30 young people went to the West and emigrated to the United States with the help of their relatives. 
Table. 3. Decline of Farmsteads in Moschendorf and Pinkamindszent

\begin{tabular}{lcccc}
\hline & \multicolumn{2}{c}{ Moschendorf } & \multicolumn{2}{c}{ Pinkamindszent } \\
Farmsteads & $\begin{array}{c}\text { Farmsteadsf } \\
\text { under 10 joch }\end{array}$ & Armsteads & $\begin{array}{c}\text { Farmsteads } \\
\text { under 10 joch }\end{array}$ \\
\hline 1900 & 101 & 74 & 154 & 105 \\
$1949 / 51$ & 139 & 121 & 116 & 78 \\
1960 & 122 & 18 & & no data available \\
1970 & 109 & 35 & & \\
1990 & 76 & 47 & & \\
\hline
\end{tabular}

Source: Statistics of agrarian business units.

In spite of the fact that we can already see in all these events and evolutions the processes of later on, we can say that the local society of both villages in the fifties was characterized by the same traditional agrarian structure and a general poverty. The basically diverging development only started in the sixties.

\section{MODERNISATION AND RESIGNATION (1960-1980)}

From the sixties on, in Moschendorf as well as in Pinkamindszent, there began to be a restructuring of the traditional agrarian society, with a large migration, and an increasing number of commuters, and for these reasons, a change in the socio-economic bases of the households. Education and professional training became more and more important.

But the modernization proceeded in differing political and economical frameworks; therefore, there were great differences in the quality and the intensity.

Two basic aspects will be examined in the following: the question of ownership, and the structures of political power. In both cases, it is the question of autonomy and the possibility of self-determination: for individuals, families, and for communities. Freedom and the right to choose, for every individual and for the local societies has been very different in the two systems.

\section{Socio-Economic Changes and Rural Exodus}

During the sixties and seventies, Moschendorf as well as the whole of Burgenland profited from the general economic development, and therefore the migration could be kept to a lower level than in Pinkamindszent 
(see table 1). Another reason is that the abandonment of agriculture took place in Moschendorf as well as in the Hungarian neighbourhood, but not as radicaly as in the latter.

In Austria the changes in the agrarian structure under a constant legal framework (concerning ownership) often means looking for another job, while keeping the farm as an additional source of income (sometimes they sell the fields and only keep the vineyards). Sometimes it also means the feminization of agriculture (the wife runs the farmstead and the husband works as a commuter in Vienna). In Hungary the sudden collectivization of the agrarian production led to a total loss of autonomy for businesses, and to dramatic changes for individuals. In Moschendorf, the socio-economic changes were accompanied by a technical modernization (of the private farms) and an intensification of the production. The heritage system was also changed: instead of giving to each of the children (now less numerous) a share of the farmstead, only one child got the farm, and the others often got a better education. But although up untill the last few years there were many investments in the agrarian production. It is probable that with the succession of the next generation, several farms will be given up.

In Pinkamindszent the second wave of collectivization in 1959/1960 took away the farmers' survival base. Although the farmers had brought their substance and their specific knowledge into the agricultural production cooperative, they saw the future of their children as outside agriculture, and hence, outside the locality. Even when they could make, a bit of profit from small private business they were not allowed to invest this money in the modernization of the private farm under the legal and economic conditions of real socialism. They invested all their spare money in private consumption, in professional education, and in the basic economic of their children outside the village. In 1990, there were in Pinkamindszent about 15 families who had a little private farmstead (as compared to 132 in 1949), butamong these families only 4 or 5 were people of the young generation. Those people wanted to stay in the village, but even the other families saw this as a personal failure. This attitude shows the change of values and the acceptance of socialist norms (discrimination against private agriculture), even by former farmers. Social ascent was no longer possible by increasing the property, but only by education and migration. Very few people started to live as commuters to Körmend, because they did not have the infrastructure or individual means of transportation that people in Burgenland had.

The dramatic increase of migration in the seventies was also accelerated by the reform in community structure (concerning 
Pinkamindszent also in 1969). In 1970, Pinkamindszent had lost its autonomy, and hence, its relative economic and political independence.

\section{Reform in Community Structure and Autonomy}

In several European countries, people tried to solve the problem of small and inefficiently working communities by amalgamating them. Also in Burgenland and in Western Hungary such small communities existed, and so in 1969, Pinkamindszent was amalgamated, along with other villages, with Vasalja; Moschendorf was amalgamated with Strem. But the loss of independence did not have the same severe consequences for Moschendorf as for Pinkamindszent. One reason may be the general economic development in Austria and Burgenland and Moschendorf's involvement in it; another reason may be that the Austrian regional policy tried to support and strengthen the periphery and the border regions. In addition, since the mayor of Moschendorf afterwards became the mayor of the greater municipality of Strem as well, he could support his village too. He has been the mayor for 30 years (1961-1991), and during this period a lot of public investments could be made in Moschendorf. In 1990 they also renovated the church with money collected in the village $(1,1$ mio AS*), which means that every household gave about $8.000 \mathrm{AS}$. We can suppose, that they have a strong solidarity and local bonds. This local identity is strengthened by a community newspaper, edited by the local government, which informs the people each month about local news. But this newspaper not only contains information; it also supports local unity and fellow feeling.

On the other side of the Iron Curtain, the amalgamation led only to decline, without further investments. During the last decades Pinkamindszent got no public investments, because neither the central state invested there, nor could the local population finance communal infrastructure by their own means. (The last great community effort was the building of a cultural center in 1960, but such strategies do not work any more). In the early seventies it was decided that there would be no primary school in Pinkamindszent and that children should go to Vasalja, the municipal center. This decision was based on the declining number of pupils: from 76 in 1963 , to 25 in 1973, to 1 in 1990. This meant another step backward in the autonomy of the community. In 1986, the local pastor died, and so even the religious believers lost their local authority.

* AS. Schilling Austrian. Monetary unit. 
Table. 4. Development and Decline of the Social and Technical Infrastructure Since 1960.

\begin{tabular}{lcc}
\hline & In Moschendorf & In Pinkamindszent \\
\hline Political Associations & got & - \\
Sport Associations & got & - \\
Cultural Associations & got & - \\
Tennis court & got & - \\
Community newspaper & got & got and lost \\
Cultural center & - & - \\
Nursery & got & lost \\
Primary School & got & - \\
Water supply & got & got \\
Street light & got & - \\
Sewage & got & - \\
Filter plant & got & - \\
New fire-brigade house & got & - \\
Renovation of the church & got & lost \\
2 inns & got & - \\
Bank office & got & \\
\hline
\end{tabular}

The differences in the public investments and the prosperity of the communities have repercussions in the private sector, particulary in the development of private housing. (See figures 4 and 5).

Originally both villages had been ribbon-built villages along a main road with typical western pannonian Streckofe (stretched-out farmsteads) which had been modernized and transformed in the sixties in Burgenland. In Pinkamindszent there was not such a rigorous transformation of the settlement, since interest in migration and private capital were lacking.

While in Pinkamindszent today $21 \%$ of the houses are empty, in Moschendorf only $6 \%$ are empty, and most of these are newly built homes, which for personal reasons are not yet in use. In Pinkamindszent the empty houses are mostly old and neglected. There are only three houses which have been restored in the original style, and they are second homes. The necessary money came from outside, which also means that outsiders see the value of the traditional architecture, and want to maintain it.

In Moschendorf the modernization of $30 \%$ of the houses took place continuously. There are only a few second homes, but in general they are owned by people from outside, not as in Pinkamindszent, where a second home often is an inherited house now owned by a person who has 


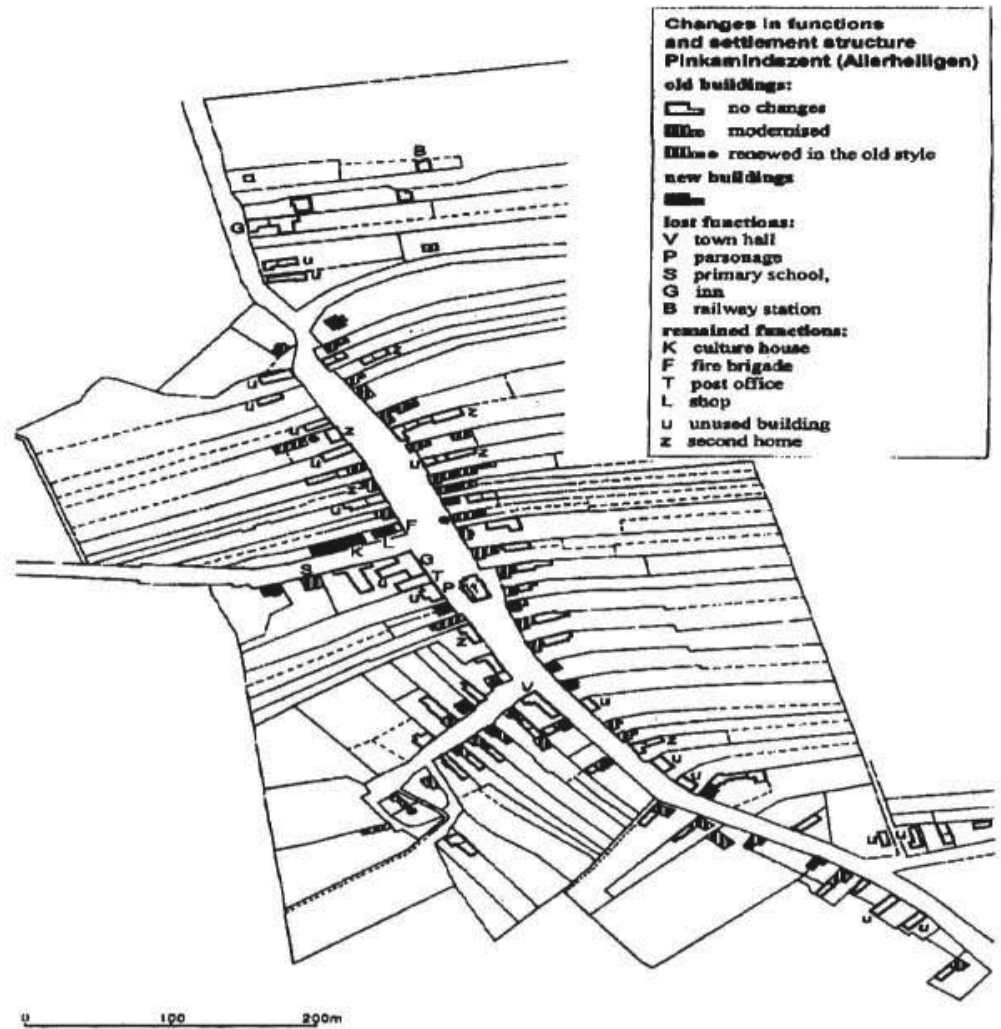

Figure 4. The Functional and Constructional Changes in the Structure of Pinkamindszer.

emigrated. People from outside the forbidden border area were not allowed to buy land or houses there.

In both villages, about $20 \%$ of the houses are still old (Moschendorf: 19,4\%, Pinkamindszent: 23\%). These are, for the most part, livellings of old people who do not want to change or modemize their homes (also they are often not able to do so).

The greatest difference between the two villages is the number of rebuilt or recently built houses. In Pinkamindszent $43 \%$ of the houses are rebuilt, mostly by young people who did not emigrate, and who invested their money in their homes during the sixties. Only $9 \%$ are newly built houses. Usually these are houses from the sixties: today elderly persons live in them. 


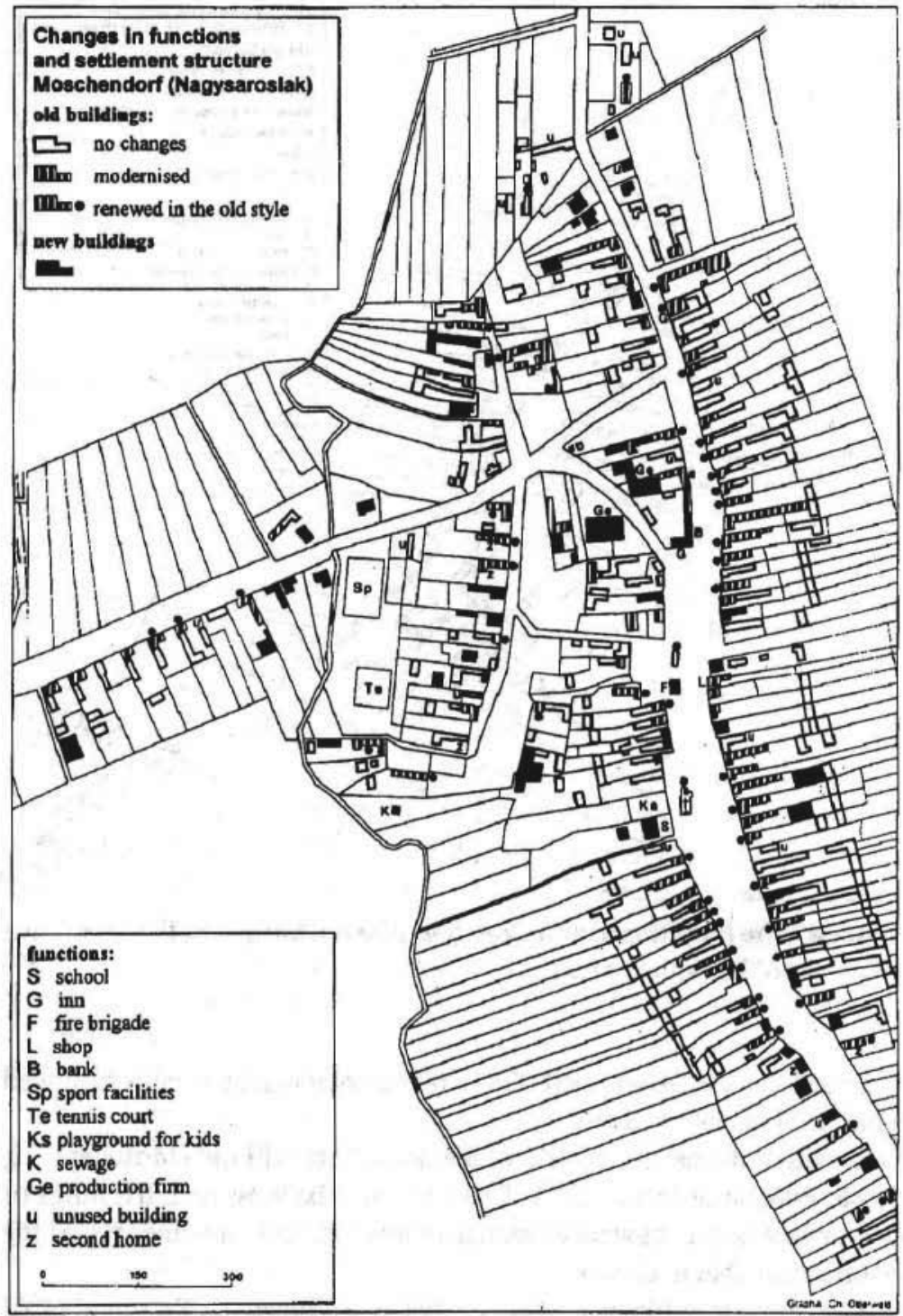

Figure 5. The Functional and Constructional Changes in the Structure of Moschendorf. 


\section{The Difference in the Quality of Life: Living Standards and Social Networks}

The consequences of the differing political and social framework in the two systems can be shown in the different standards of living, the social relations and the individual possibilities for personal advancement.

\section{The Quality of Housing, Mobility and Consumer Habits.}

In Moschendorf, about 205 of the houses are modernized and rebuilt, $30 \%$; are new. The traditional form of the ribbon-built village has been altered and amplified. The fact that about $80 \%$ of the buildings kept in repair, rebuilt, or newly built, shows a permanent investment, which needs, besides the capital (and the legal framework and support) local bonds also, and an optimistic view of the future. In Moschendorf most of the apartments have more than 100 square meters, $17.4 \%$ have more than 180 . This size can also be expressed with reference to the number of rooms. While in Pinkamindszent most of the apartments have two rooms, in Moschendorf $60.8 \%$ have four or more rooms, due to of the high number of households of more than one generation and to the high rate of new buildings.

In Pinkamindszent nearly all apartments are at the most, about 100 square meters; most of them have between 60 and 80 square meters, which means two rooms. (Among the 107 flats of Pinkamindszent, 21 have one room, 67 two rooms and only 19 three or more rooms. Also, the new buildings and rebuilt houses are the same size (two rooms) as the traditional farmsteads. This dramatic decline in the standard of living and in the buildings is all the more striking because Pinkamindszent at the turn of the century had buildings of a much more modern style, and built with better materials than in other nearly villages, such as Moschendorf.

Concerning equipment, there is a similar difference between the two villages: In Pinkamindszent $53.2 \%$ of the houses have a full bath; only 9.4\% have central heating too. In Moschendorf $98.5 \%$ have a full bath; $76.8 \%$ have central heating too as well. Also, considering domestic appliances and entertainment electronics, we can see the same gap. In Moschendorf most of the families have several household appliances (refrigerator, washing machine, vacuum cleaner, electric range, mixer) sometimes several appliances of the same type (e.g. freezers); in Pinkamindszent nearly all have only freezers to conserve their agricultural products. While nearly all Hungarian households have TV, just as in Moschendorf, in Moschendorf they have also video and $\mathrm{HiFi}$, which can 
not be found in Pinkamindszent. In Moschendorf $96 \%$ of the households have a telephone; in Pinkamindszent only three households have phones and they only work via operator. That meant as well that the locality could not participate in the military investment, so there were no advantages for the civil infrastructure.

Conccerning personal mobility and individual transportation, the situation is worse in Hungary: $56 \%$ of the households in Pinkamindszent have no car, as compared to $13 \%$ in Moschendorf (mostly old people). But 22\% of the households in Moschendorf have two or three cars; no household in Hungary has more than one. So Pinkamindszent is much more dependent on public transportation ( 3 or 4 times daily a bus to Körmend), and neighbours and relatives are much more important. This cannot be explained simply by a greater economic prosperity; it also implies different household structure.

In the two villages we find today a completely different demographic structure, In Moschendorf we have a quite normal structure for westem Europe, but in Pinkamindszent the demographic erosion of the last decades brought about significant rise in the ratio of old people to the total population (see figure 6).

In Pinkamindszent in 1990, only $22 \%$ of the households had more than two persons; in Moschendorf, $65 \%$. The typical household of

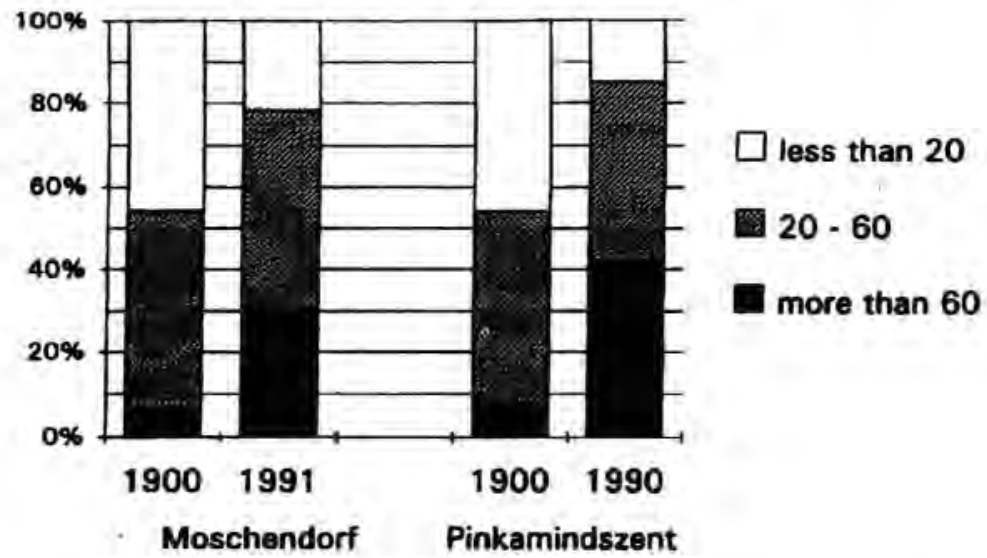

Figure 6. The Different Age Structure of the Population in Moschendorf and Pinkamindszent in 1900 and 1980. 
Pinkamindszent has two persons (53\%); $19 \%$ have one person. In Moschendorf there are fewer than $10 \%$ singles; only $26 \%$ of the households have two persons. These households with one or two persons generally consist of elderly people, which is the typical situation for Pinkamindszent. In Moschendorf one third of the households consist of more than one generation, who make a contribution to the household economy.

The different consumer habits can be explained by this difference of wealth, the socio-economic development and the rise of the ratio of old people in proportion to the total population.

In Moschendorf $20.3 \%$ of the population goes out to eat in a restaurant weekly and $24.6 \%$ monthly. In Pinkamindszent $71.9 \%$ of the families never go out to eat. The same can be said of travelling: In Moschendorf nearly all families reported one or more longer journeys during the last few years, and also for farm families, a trip to a foreign country, or to another federal state for a vacation is a quite usual consumer habit. Traveling does not mean, as it does in Pinkamindszent, simply visiting relatives; it means holidays, often organized by a travel agency, and bus trips or city tours in Europe or abroad (we heard about Sweden, France, Switzerland, Greece, Israel, Turkey, USA, Tunisia, Canada). In Pinkamindszent only two-thirds of the persons interviewed spoke about a longer journey in the last few years; 13 of them had been to a foreign country. Those had made religious pilgrimages, organized by the church (to Mariazell, Austria; to Lourdes, France) or visits to see relatives. Travels in Hungary are planned in order to visit the children in the towns (Szombathely, Budapest), longer trips are for shopping (in Vienna). Moschendorfers visits to the neighbouring region use for shopping, eating in restaurants, visits to the doctor or the hairdresser; Hungarians go for religious pilgrimages or church feasts.

\section{Integration and Decay of the Local Communities}

Corresponding to the difference in the standard of living in the public and private life of the two communities, and corresponding to the different demographic structures, we also find two different levels of social life in the two villages.

This depends overall on the possibilities for the development of local autonomy, or unfurther-developed or suddenly-cut local traditions and on the existence of a social climate free from repressions. In Moschendorf, the social life of the local society did not suffer any restriction because of the amalgamation. There are eight social associations; among them, three have existed since 1971, and nearly all families and second-home owners 
belong to at least one of these. Besides the traditional rural associations (fire-brigades and the men's glee club) and the organizations of the political parties (e.g. for women and for elderly persons) we can also find a tennis club, an association for wine-grape growers, and a cultural club as organizers of the local museum of wines. Even if winegrowing lost its economic importance ( 60 families have vineyards), the wine cellars would still be a center for social life (where now women are also admitted!). With the foundation of the museum of wines and the culture club (1982), in which nearly all families participate ( 220 members), by means of regular events they succeeded in giving new life to old traditions and in strengthering the cohesiveness and the identity of the local society. In these groups, as well as in another association, the seniors club, life revolves around the mayor. The clique around the mayor in the senior club where in general the old farmers meet, still has a great influence on public opinion in the locality: e.g. concerning the opening of a local border station. As there have arisen local counter-elitist groups who articulate their opinions very emphatically, we can see that there are young people interested in local politics. Their involvement also shows that values are changing today in Moschendorf: with the acceptance of an urban lifestyle and corresponding activities (like playing tennis in a special club) now comes the acceptance of "green" values. Often such "green" or postmodern ideas are in conflict with the older values commonly held or with progress, and even though the opening of the international border was not an actual problem in October, 1990, people protested against the traffic which would come with a new border station. For young people and second-home owners, the tranquility, the pure air, and the healthy environment are resources which must not be compromised.

This dispute in the local society shows that there are several well-articulated groups (elites), who can support their point of view in an open discussion. In general, we may emphasize that in such an wealthy and politically-free framework, even the periphery can become a value for itself.

On the other side of the border, we see a totally different picture: owing to the loss of institutions (primary school, parish, municipality, center of the agricultural production cooperative, police station, railway station, etc.) there also was a brain drain, a loss of local intelligence. Through the demographic and social erosion, caused by migration, all the people with initiative and all the involved people were lost. The structure of the local society is nearly dissolved.

Just as Moschendorf is characterized by a diversity of communication and integration, so in Pinkamindszent we can speak about a deformed 
social structure. In this society there was no possibility for free development of objectives and articulation of political interest, no possibility to renew the social potential. Untill 1989, a small group of former members of the agricultural production cooperative met nearly every day, but they had no legal power, and no potential to influence local development. Social contacts in the village were reduced to neighbors helping each others; new social structures had not been developed and the existing possibilities for communication were continuously reduced by death and migration.

Social interaction, even in neighbors helping each others, is mostly among relatives; public life gets poorer and poorer. About $28 \%$ say that they have contacts mainly with relatives. In Moschendorf, only $7.2 \%$ said this, while $49.3 \%$ mainly had contacts with neighbours and friends. In Pinkamindszent, contacts with neighbours was said to be $15.6 \%$, with friends, 9.4\%. In social life contacts with the (migratcd) children are dominat. "We always wait for the children". They wait for them in several senses: not only with food in the freezer, filled with products from the garden and with home-produced meals, but also the whole village waits for those who have been successful in town; those persons of the community who got an academic education or who had powerful positions "in town" had always been the hope of the local society. In fact, those who had a job in the national bank played an important role in the hopes of the people of Pinkamindszent.

Since the local society of Pinkamindszent has up till now needed the financial and social power of the migrated to survive, one cannot believe that in the future they will be able to stop the socio-economic and demographic erosion by themselves. The reserves of this society are exhausted. Also for the political articulation they need help today: in the new, democratically-elected community council there is no person born in Pinkamindszent. It seems that the local society of Pinkamindszent has no possibility of profiting from the political changes on its own.

\section{NEW PERSPECTIVES?}

The point of view regarding the political evolution, and the expectations regarding the future of their own local area are totally different in the two villages: while in Moschendorf only a small group hopes for an economic profit, and some others are afraid of the loss of their seclusion, in Pinkamindszent the opening of the border has become the great hope. Both villages are confronted with a radical change. In Moschendorf this leads to a re-evaluation of the geographical location in 
the periphery, and opens up the possibility of a democratic discussion, and development of objectives. In Pinkamindszent, they have to find ways to take advantage of their opportunities. (With the money they now get from the state as a small, but independant community, they want to build a water supply, and a sewage treatment plant). But as the means of the people themselves are very restricted, and there are only very few young people with initiative, they will still need help from outside, from the state and the migrated children. They hope that some of these will come back, renovate their houses and push for a little economic development. Even a little economic upswing could stop the demographic erosion and give new hope. But in spite of the political democratization and liberalization, and the recent community autonomy, the quality of life and the individual opportunities to sacceed will still be different in the two villages for a long time. It will take decades for the ruptures of this century to be smoothed out.

\section{REFERENCES}

DUJMOVITS, W, 1975, Die Amerikawanderung der Burgenlander. Stegerbach.

- 1990. "Südburgenland - Peripherie ohne Grenzen". In: Alfons, H. (Hrsg.). Regionalentwicklung und Kooperation im Grenzgebiet Osterreich/Ungarn (Int. Seminar Stadtschlaining). Schriftenreihe Nr. 59, p. 14-30, Bundesanstalt für Agrarwirtschaft, Wien.

KOVACS, K. 1987. Integráció vagy széttoredezés? Társadalomszerkezeti változások egy dunántúli aprofalu, Magyarlukafa példajá. (Integration or Disintegration. Sociostructural Changes on the Example of a Small Transdanubian Village) - MTA RKK Kutatasi Eredményei 5., Pecs.

- 1990. Urbanizáció alulnézetbol (Az utóbbi évtizedek társadalomszerkezeti változásal az aprofalvas régióban) (Urbanization the Groand up - the Sociostructural Changes of the Latter Decades in a Region of Small Villages). In: Ter - Idö - Tárdasadalom. Huszonegy tanulmány Enyedi Gyorgynek. MTA RKK. Pecs

ROMSICS, I. 1985. A parasztság és a forradalmak kora. In: Valóság 3, Budapest.

SEGALEN, M. 1984. "Sein Teil haben", Geschwisterbeziehungen in einem egalitären Vererbungssystem. In: Medick, H. Sabean, D. (1984): Emotionen und materielle Interessen. Sozialanthropologische und historische Beitrage zur Familienforschung. 
Veröffentlichungen des Max - Planck-Institutes für Geschichte, 1975, Göttingen: Vandenhoeck \& Ruprecht.

WASTL-WALTER, Doris., Monika Varadi and K. Kocsis. 1993, "Leben im Dorf an der Grenze". In; M. Seger, P. Beluszky (Hg.) Bruchlinie Eiserner Vorhang, Böhlau, Wien. 